\title{
Great Plains Ladies'-tresses (Spiranthes magnicamporum) in the Lower Great Lakes Region and a New Record for New York State
}

\author{
DANIEL F. BRUNTON
}

216 Lincoln Heights Road, Ottawa, Ontario KIA 8A8 Canada; email: bruntonconsulting@rogers.com

Brunton, Daniel F. 2015. Great Plains Ladies'-tresses (Spiranthes magnicamporum) in the lower Great Lakes region and a new record for New York State. Canadian Field-Naturalist 129(2): 183-188.

Six populations of Great Plains Ladies'-tresses (Spiranthes magnicamporum Sheviak) have recently been discovered in three locations east of the lower Great Lakes region of Canada and the United States. The possible occurrence of $S$. cernua $\times$ magnicamporum hybrids was detected at one New York site. These discoveries are from both natural alvar and disturbed meadow and shore sites. The new records suggest that $S$. magnicamporum occurs more widely than was suspected previously, its presence perhaps masked by its similarity to the common $S$. cernua (L.) Richard. Eastern occurrences may represent a combination of post-glacial relict populations, responses to climate change, and the results of long-distance dispersal events. These range extensions constitute the most easterly known populations of $S$. magnicamporum in North America. They also represent new records for New York State (including Jefferson and St. Lawrence Counties) and for the City of Ottawa in Ontario.

Key Words: Great Plains Ladies'-tresses; Spiranthes magnicamporum; New York; Ontario; alvar; range extension; Ottawa; post-glacial relict

\section{Introduction}

As suggested by its common name, Great Plains Ladies'-tresses (Spiranthes magnicamporum Sheviak; Orchidaceae) is predominantly a western grasslands diploid species. The core distribution of this recently described taxon is central North America (Figure 1). Beyond there, S. magnicamporum is typically considered a rare disjunct, with isolated population clusters east to central Kentucky, western Virginia, southern Ohio, and southwestern Ontario (Sheviak and Brown 2002). Until recently, the most easterly occurrences were known only on the basis of 19th-century specimens from two presumed extirpated populations in southeastern Pennsylvania (Rhodes and Block 2000). It is a species of conservation concern in all or most jurisdictions beyond its core range. That is certainly true in Canada

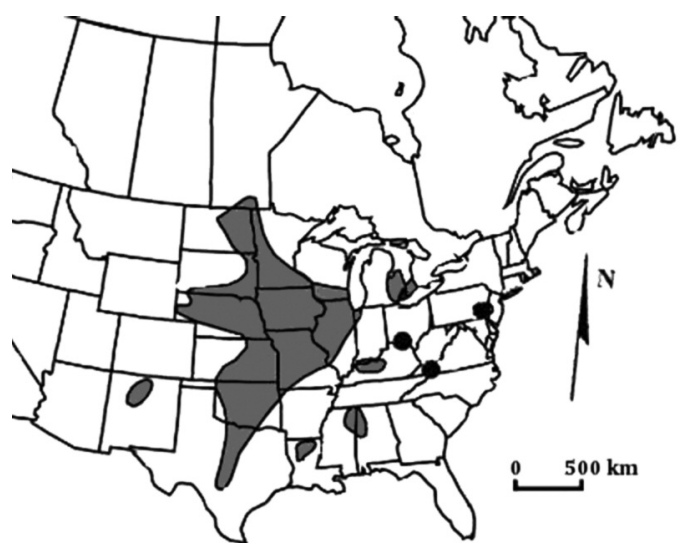

FIGURE 1. Distribution of Great Plains Ladies'-tresses (Spiranthes magnicamporum) in North America (Sheviak and Brown 2002). where it was known from several populations in a small area of southern Manitoba (Ames et al. 2005; Brouillet et al. 2010+) and from scattered populations in southwestern Ontario (Oldham and Brinker 2009).

In September 2013, a large population of Spiranthes magnicamporum was discovered in relict prairie habitat on the Burnt Lands alvar, Lanark County, Ontario, by P. M. Catling (Reddoch et al. 2013). That discovery stimulated additional field investigations and the location of new populations. This article documents those new populations and reviews the distribution and habitat of the species east of the Great Lakes.

\section{Additional Eastern Populations}

The association between Spiranthes magnicamporum and the provincially rare and distinctive alvar grass Northern Dropseed (Sporobolus heterolepis (A. Gray) A. Gray) was noted during examinations of its preferred habitat in the Burnt Lands alvar and was used as a field aid for the discovery of additional populations. In September 2014, I conducted searches for this orchid in alvar habitat supporting $S$. heterolepis populations in the City of Ottawa portion of the Burnt Lands alvar and in similar sites between Belleville and Kingston in southern Hastings and Lennox \& Addington Counties along the north shore of Lake Ontario. These searches were unsuccessful, perhaps because the sites examined were drier than the $S$. magnicamporum site on the Lanark County portion of the Burnt Lands alvar.

In 2014, however, I discovered a small population of Spiranthes magnicamporum in moist alvar habitat $5.1 \mathrm{~km}$ northeast of Chaumont in Jefferson County, New York, in the Chaumont Barren Reserve (Figures 2 and 3). Spiranthes specialists P. M. Catling and C. J. Sheviak verified the identification from photographs of the

A contribution towards the cost of this publication has been provided by the Thomas Manning Memorial Fund of the Ottawa Field-Naturalist's Club. 
Chaumont Barren plants. This represents the first record of S. magnicamporum for the state of New York (Mitchell 1986; Weldy et al. 2015).

Twelve flowering plants of Spiranthes magnicamporum were initially found at the Chaumont Barren site, just coming into peak flower on 7 September 2014. The strong vanilla-like fragrance typical of this species was evident even in these mostly immature blooms. Later, 50 flowering plants were found there, including scattered individuals in a nearby Sporobolus heterolepis meadow, still flowering on 23 September 2014 (Holly Bickerton, personal communication).

On 13 September 2014, approximately 90 Spiranthes magnicamporum plants were found by Steven Daniel and Anne Johnson in a separate alvar population approximately $1 \mathrm{~km}$ from the first Chaumont Barren site. These plants had the leafless stems, late-flowering habit, and strong floral fragrance of $S$. magnicamporum. However, their flowers exhibited morphological features somewhat intermediate between those of $S$. magnicamporum and Nodding Ladies-tresses ( $S$. cernua (L.) Richard), the common, earlier-flowering, and typically odourless tetraploid species with which diploid $S$. magnicamporum can be confused. Although no $S$. cernua plants were noted in 2014 at the Chaumont Barren, the potential for this second population to represent hybrids warrants further investigation. Triploid hybrids between these species are known but are dif- ficult to confirm without cytological analyses (Sheviak 1991).

Spiranthes magnicamporum was found at a second northern New York location shortly after the Chaumont discoveries. On 25 September 2014, Henry Steger located 76 plants in a calcareous roadside meadow at Hopson's Bay along the St. Lawrence River at Massena, St. Lawrence County. Another Massena population (approximately 20 plants) was found shortly thereafter (2 October 2014) by Anne Johnson and Steven Daniel in a similarly low, disturbed (possible landfill) site along the north side of the Wiley Dondero Canal in Robert Moses State Park, approximately $6 \mathrm{~km}$ east along the St. Lawrence River from Hopson's Bay (A. Johnson in Brunton 2015). The Massena populations are approximately $135 \mathrm{~km}$ east of the Chaumont Barren Reserve.

In addition to the New York populations, a second eastern Ontario population was discovered in 2014. On 19 September 2014, Henry Steger found 16 plants just coming into flower in the City of Ottawa portion of the Burnt Lands alvar in Burnt Lands Provincial Park. The plants were in a formerly treed but now graminoid-dominated alvar meadow that was burned in a wildfire in June 1999 (Catling 2009). This population is located approximately $4 \mathrm{~km}$ southeast of the much larger Lanark County Burnt Lands alvar population found in 2013 and is the first record for the City of Ottawa (Brunton 2005).

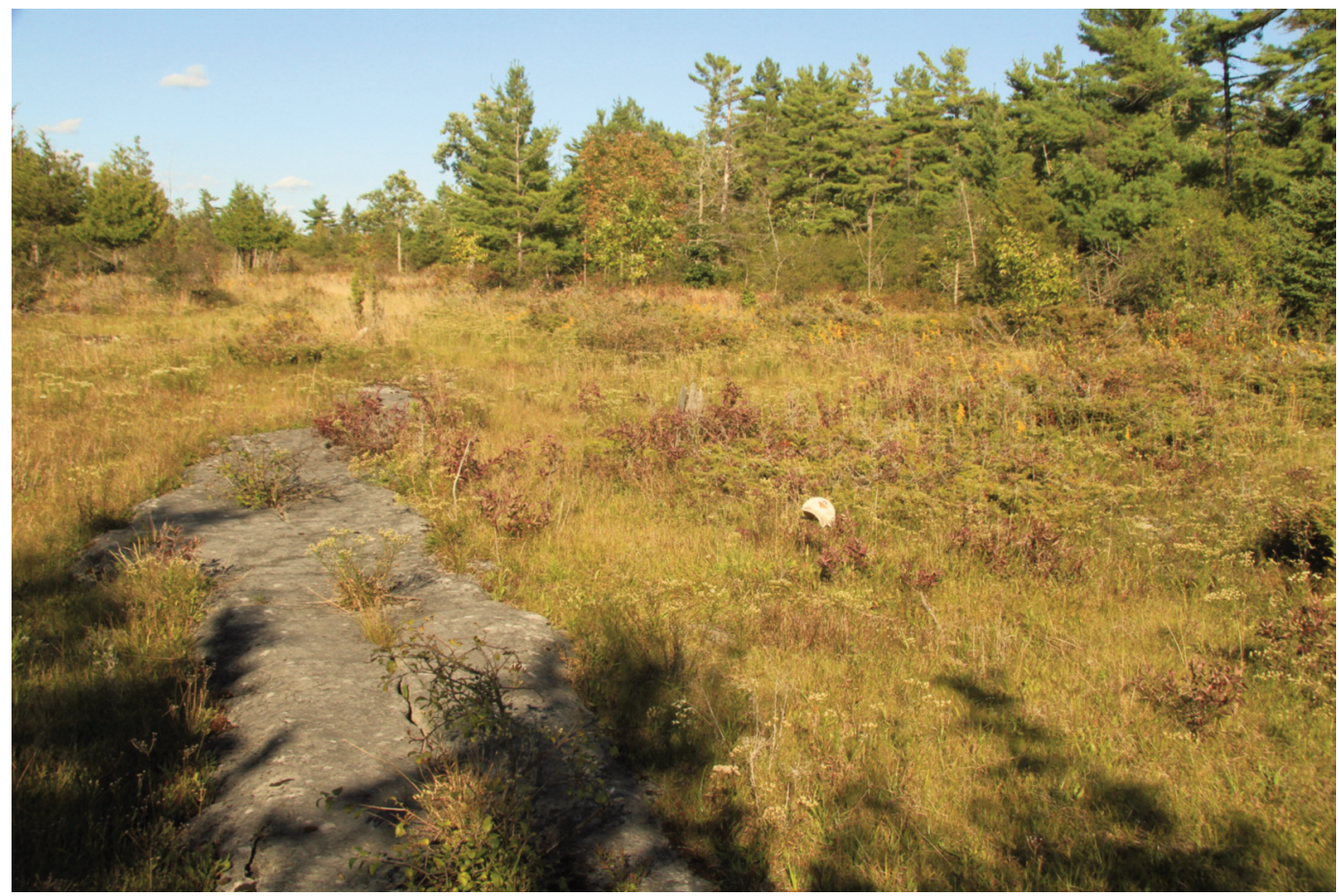

FIgURE 2. Site and habitat of Great Plains Ladies'-tresses (Spiranthes magnicamporum) at the Chaumont Barren Reserve, Jefferson County, New York (7 September 2014). Photo: D. F. Brunton. 


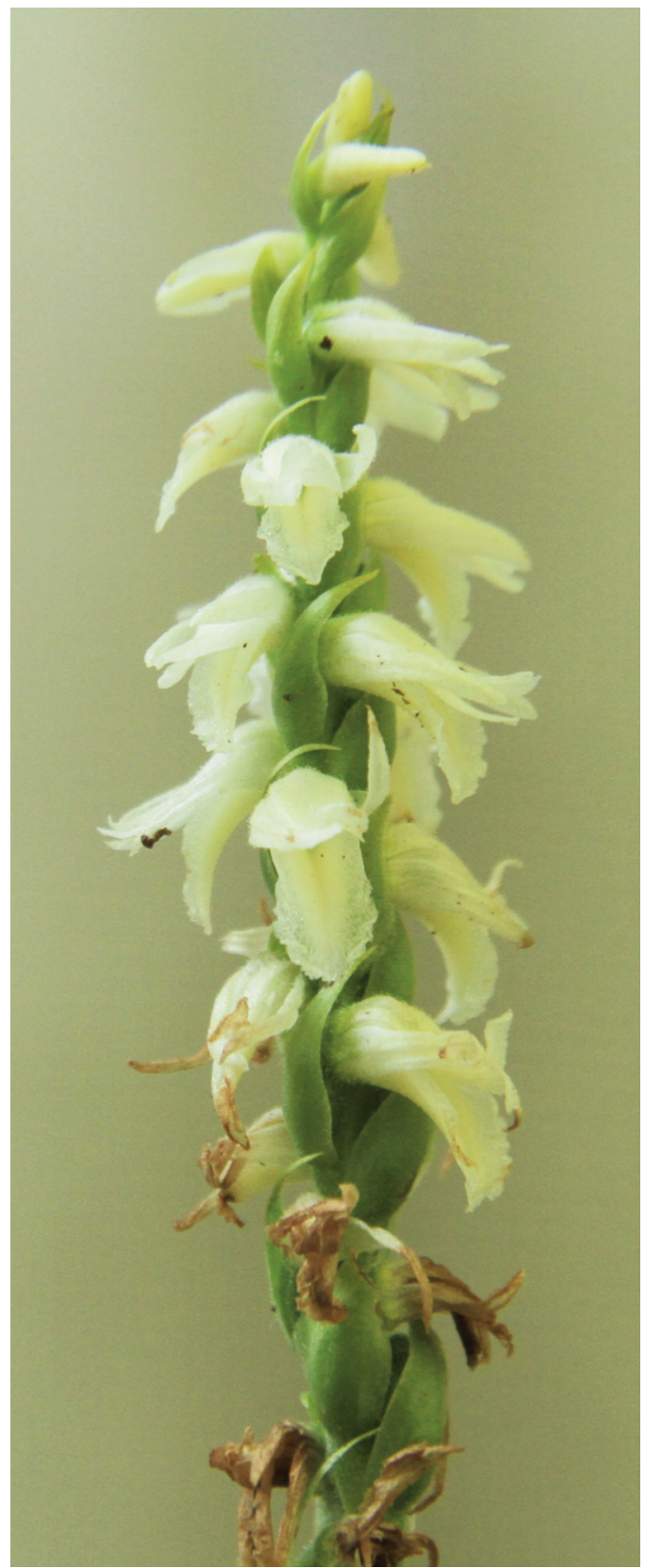

FIGURE 3. Flowering spike of Great Plains Ladies'-tresses (Spiranthes magnicamporum) at the Chaumont Barren Reserve, Jefferson County, New York (7 September 2014). Photo: D. F. Brunton.

A voucher specimen from the initial Chaumont Barren population of Spiranthes magnicamporum (D. F. Brunton 18,833) has been deposited in the New York State (NYS) herbarium. Digital photographs of the second Chaumont Barren population, both St. Lawrence County populations, and plants from the City of Ottawa site were obtained for documentation and verification purposes.

Figure 4 illustrates the known distribution of Spiranthes magnicamporum in Ontario and New York State. From an initial understanding of the species location close to the shores of Lakes Huron and Erie (Whiting and Catling 1986), its distribution in southwestern Ontario is now recognized to extend across virtually all of the Carolinian zone. (Note: Oldham and Brinker [2009] records shown in Figure 4 denote counties, not exact locations, where inland populations have been found since 1982.)

\section{Spiranthes magnicamporum Habitats and Origins}

The recently discovered populations of Spiranthes magnicamporum in the lower Great Lakes region occupy two quite different habitats, possibly reflecting dispersal at different time periods. Whiting and Catling (1986) describe the preferred habitat within the more or less continuous Ontario range (shaded area of Figure 4) as low prairies, littoral meadows, or even disturbed upland meadows over calcareous substrate. Similarly, Sheviak and Brown (2002) describe the plant as occurring across its North American range in "dry to wet prairies and fens," as do Rhodes and Block (2000) for Pennsylvania, Voss and Reznicek (2012) for Michigan, and Swink and Wilhelm (1994) for the Chicago region. A clear explanation for why two very different habitats appear to be used and what may have led to the occurrence of $S$. magnicamporum populations in this area will require additional research, including more field investigation in eastern Ontario, northern New York, and southwestern Quebec. There is sufficient evidence, however, to permit reasonable speculation on some likely possibilities.

The habitat of Spiranthes magnicamporum populations in the flooded section of the St. Lawrence River, also known as the St. Lawrence Seaway, is consistent with that of its core range, especially the more disturbed meadow habitats. It grows there in low, seasonally wet meadows in calcareous silty-sand and gravel substrate with Pringle's Aster (Symphyotrichum pilosum (Willdenow) G. L. Nesom ssp. pringlei (A. Gray) G. L. Nesom), White Flat-top Goldenrod (Solidago ptarmicoides (Nees) B. Boivin), and Greater Fringed Gentian (Gentianopsis crinita (Froelich) Ma) (H. Steger, personal communication) and at Robert Moses State Park, also with spikerushes, Eleocharis elliptica Kunth and the regionally rare Eleocharis quinqueflora (Hartman) O. Schwarz (Anne Johnson, personal communication; Eldblom and Johnson 2010)).

Contrary to that pattern, however, beyond the Carolinian zone in Ontario and the Chaumont Barren of New York, Spiranthes magnicamporum is found exclusively in alvar habitat. Plants at the Chaumont Barren, Burnt Lands, and Carden Plain (City of Kawartha, east of Lake Simcoe) alvars grow over limestone bedrock in the thin, seasonally moist turf of open meadows and glades in various combinations of Sporobolus hetero- 


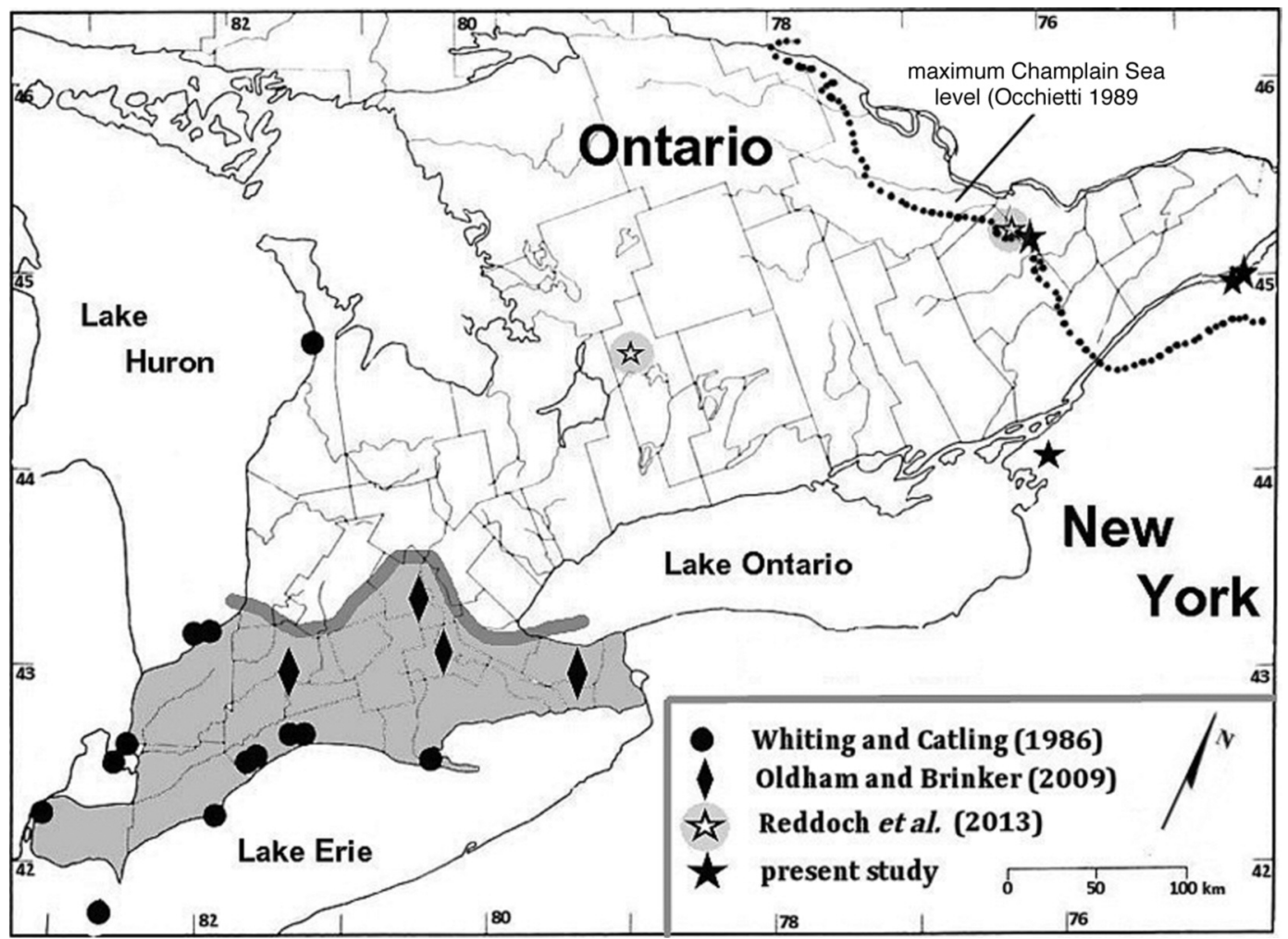

FIGURE 4. Distribution of Great Plains Ladies'-tresses (Spiranthes magnicamporum) in Ontario and New York (shaded area indicates continuous range within Canada).

lepis, Ensheathed Dropseed (Sporobolus vaginiflorus (Torrey ex A. Gray) Alph. Wood var. vaginiflorus), Solidago ptarmicoides, Prairie Smoke (Geum triflorum Pursh), Canada Bluets (Houstonia longifolia Gaertner [syn. Houstonia canadensis (Willdenow) Fosberg]), Wiry Panicgrass (Panicum flexile (Gattinger) Scribner), and/or Poverty Grass (Danthonia spicata (L.) P. Beauvois ex Roemer \& Schultes). Elsewhere in North America, "grassy limestone barrens" in Virginia (Weakley et al. 2012) appear similar to that of southern Ontario alvar sites. Charles Sheviak (personal communication) notes that "the species sometimes occurs in very shallow soils over limestone in the heart of its prairie range too."

It seems significant that the Spiranthes magnicamporum sites on the Carden Plain and Burnt Lands alvars are geographically situated within a complex of postglacial Great Lakes drainage features such as stranded beaches, drainage outlet channels, and fossilized dunes (Chapman and Putnam 1984). The presence of these populations and their distinctive Great Lakes and western flora and faunal associates may be related to postglacial landscape structure and to revegetation processes thought to have provided prehistoric migration opportunities (Catling and Brownell 1995; Reschke et al. 1999). These S. magnicamporum populations, then, may represent relicts of the time when landscape forming processes were particularly active in the lower Great Lakes region (8000-12 000 years ago; Occhietti 1989). The optimum time for the migration of western and prairie species into the lower Great Lakes region including the currently known Ontario and New York range of S. magnicamporum would more likely have been during the hypsithermal period that prevailed approximately $8000-9000$ years ago when conditions were warmer and drier than they are in contemporary times (Dadswell 1974; Mardis 2014).

Unlike those of other easternmost populations, however, Spiranthes magnicamporum sites along the St. Lawrence Seaway are distinctive by virtue of their prolonged, deep submergence in the post-glacial Atlantic Ocean embayment, the Champlain Sea (Figure 4). The Chaumont Barren alvar is situated beyond the reach of the sea and would have been available for revegetation shortly after deglaciation of the local landscape about 11000 years ago (Karrow 1989). The Burnt Lands alvar (elevation 145-155 m above sea level) is situated at the western limit of the Champlain Sea (Russell and Cummings 2009). Current Burnt Lands S. magnicamporum sites are either at or only slightly beneath where the sea's maximum elevation $(155 \mathrm{~m}$ above sea level) reached approximately 12000 years 
ago (Occhietti 1989) and thus were available for revegetation shortly thereafter (Brunton 1986). Accordingly, potential colonization of terrestrial habitats at both the Burnt Lands and the Chaumont Barren would have been possible during the warmer, drier hypsithermal period.

In contrast, the substantially lower elevation (approximately $64 \mathrm{~m}$ above sea level) St. Lawrence Seaway sites would have been available for colonization for a much shorter post-glacial period, having remained submerged beneath the waters of the Champlain Sea and its subsequent freshwater phase, Lake Lampsilis (Russell and Cummings 2009). This inundation extended to approximately 8000 years ago (Mardis 2014). Accordingly, occupation of the St. Lawrence Seaway sites would have occurred under at least close to contemporary climatic and vegetation conditions as they became established subsequent to the hypsithermal period.

Another possible explanation for the occurrence of Spiranthes magnicamporum at the apparently regionally atypical St. Lawrence Seaway sites may be longdistance wind transport of seed, as has been shown for numerous orchid species (Arditt and Ghani 2000). Were that the case here, however, a more frequent and random distribution across this commonly available, disturbed habitat would be expected.

Range expansion due to climate change has been used to explain recent discoveries of Spiranthes cernua in northern Ontario beyond its previously known range (Catling and Oldham 2011). That may apply to Spiranthes magnicamporum as well. Were that the explanation for these eastern $S$. magnicamporum populations, however, a more random distribution and a lower proportion of occurrences in rare habitat known for supporting relict western flora would be expected.

\section{Spiranthes magnicamporum Status}

Eastern Ontario and northern New York populations represent the easternmost extant Spiranthes magnicamporum in North America. Given the success of relatively limited 2014 field investigations, the discovery of additional populations in the lower Great Lakes region seems probable, particularly along the St. Lawrence Seaway shores of northern New York, in adjacent Stormont, Dundas and Glengarry County of southeastern Ontario and perhaps in extreme southwestern Quebec. Even if additional populations are discovered, however, it is expected that $S$. magnicamporum will remain a rare and biogeographically interesting element of the regional flora.

\section{Acknowledgements}

My thanks to Paul M. Catling for sharing his Burnt Lands alvar discoveries, offering a wealth of ecological information, inspiring the initial Chaumont Barrens investigation, and providing verifications for later discoveries. Charles S. Sheviak also was quick to provide both specimen verification and valuable insights on Spiranthes magnicamporum. New York botanists Steven
Daniel and Anne Johnson immediately employed their expert field knowledge and shared the success of those efforts. Similarly, Ontario field botanists Henry Steger, Wasyl Bakowski, and Holly Bickerton shared their $S$. magnicamporum discoveries and experience from New York and Ontario. The manuscript benefitted significantly from input and comments by Paul Catling, Holly Bickerton, Charles Sheviak, and Joyce Reddoch.

\section{Document Cited}

Brouillet, L., F. Coursol, S. J. Meades, M. Favreau, M. Anions, P. Bélisle, and P. Desmet. 2010+. All 2,776,693 records [Manitoba Spiranthes magnicamporum specimens]. In VASCAN, the database of vascular plants of Canada. Accessed 9 June 2015. http://data.canadensys.net/explorer /en/search?view=table\&1_f=16\&1_o=eq\&1_v_1=Spiran 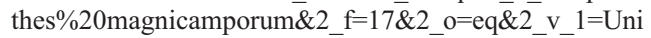 versity $\% 20 \mathrm{of} \% 20$ Manitoba.

Mardis, S. 2014. A geohistory of the Lake Champlain Basin. http://www.academia.edu/7588255/A_Geohistory_of_the _Lake_Champlain_Basin.

Weldy, T., D. Werier, and A. Nelson. 2015. [Spiranthes] New York Flora Atlas. New York Flora Association, Albany, New York, USA. Accessed 9 June 2015. http://newyork .plantatlas.usf.edu/Results.aspx.

\section{Literature Cited}

Arditt, J., and A. K. A. Ghani. 2000. Numerical and physical properties of orchid seeds and their biological implications. New Phytologist 145: 367-421.

Ames, D., P. B. Acheson, L. Heshka, B. Joyce, J. Neufeld, R. Reeves, E. Reimer, and I. Ward. 2005. Orchids of Manitoba: a Field Guide. Native Orchid Conservation Society, Winnipeg, Manitoba, Canada.

Brunton, D. F. 1986. Natural environment inventory of the Burnt Lands, Regional Municipality of Ottawa-Carleton/ Lanark, Ontario. Ontario Ministry of Natural Resources, Kemptville, Ontario, Canada.

Brunton, D. F. 2005. Vascular plants of the City of Ottawa, with identification of significant species. Appendix A in Urban Natural Areas Environmental Evaluation Study, Final Report. Muncaster Environmental Planning and Brunton Consulting Services, Planning and Growth Management Department, City of Ottawa, Ottawa.

Brunton, D. F. 2015. Great Plains Ladies'-tresses (Spiranthes magnicamporum) discovered in New York. New York Flora Association Newsletter: 26: 1-4.

Catling, P. 2009. Vascular plant biodiversity in burned and unburned alvar woodland: more evidence of the importance of disturbance to biodiversity and conservation. Canadian Field-Naturalist 123: 240-245.

Catling, P. M., and V. Brownell. 1995. A review of the alvars of the Great Lakes Region: distribution, floristic composition, biogeography and protection. Canadian FieldNaturalist 109: 143-171.

Catling, P. M., and M. J. Oldham. 2011. Recent expansion of Spiranthes cernua (Orchidaceae) into northern Ontario due to climate change? Canadian Field-Naturalist 125: 34 40.

Chapman, L. J., and D. F. Putnam. 1984. The Physiography of Southern Ontario. Third edition. Ontario Geological Survey Special Volume 2. Ministry of Natural Resources, Toronto, Ontario, Canada. 
Dadswell, M. J. 1974. Postglacial geological history. Pages 11-18 in Fishes of Canada's National Capital Region. Edited by D. E. McAllister and B. W. Coad. Department of the Environment, Ottawa, Ontario, Canada.

Eldblom, N. C., and A. M. Johnson. 2010. Plants of St. Lawrence County, NY: An Annotated Checklist of Vascular Flora. Bloated Toe Publishing, Peru, New York, USA.

Karrow, P. F. 1989. Quaternary geology of the Great Lakes subregion. Pages 326-350 and 379-388 in Quaternary Geology of Canada and Greenland. Edited by R. J. Fulton. Geological Survey of Canada, Ottawa, Ontario, Canada.

Mitchell, R. S. 1986. A checklist of New York State plants. Bulletin 458. New York State Museum, Albany, New York, USA.

Occhietti, S. 1989. Quaternary geology of St. Lawrence Valley and adjacent Appalachian subregion. Pages 350-388 in Quaternary Geology of Canada and Greenland. Edited by R. J. Fulton. Geological Survey of Canada, Ottawa, Ontario, Canada.

Oldham, M. J., and S. R. Brinker. 2009. Rare Vascular Plants of Ontario. Fourth edition. Natural Heritage Information Centre, Ontario Ministry of Natural Resources, Peterborough, Ontario, Canada.

Reddoch, J. M., P. M. Catling, and A. H. Reddoch. 2013. Great Plains Ladies'-tresses, Spiranthes magnicamporum: disjunct in Eastern Ontario and a new orchid species for the Ottawa District and Lanark County. Canadian FieldNaturalist 127: 348-351.

Reschke, C., R. Reid, J. Jones, T. Feeney, and H. Potter. 1999. Conserving Great Lakes alvars: final technical report of the International Alvar Conservation Initiative. The Nature Conservancy, Chicago, Illinois, USA.
Rhodes, A. F., and T. A. Block. 2000. The Plants of Pennsylvania, an Illustrated Manual. University of Pennsylvania Press, Philadelphia, Pennsylvania, USA.

Russell, H. A. J., and D. I. Cummings. 2009. Deglaciation of the Champlain Sea Basin, Eastern Ontario: 72nd Friends of the Pleistocene Reunion, June 6-7, 2009, Ottawa Ontario. Geological Survey of Canada, Ottawa, Ontario, Canada.

Sheviak, C. J. 1991. Morphological variation in the compilospecies Spiranthes cernua (L.) L.C. Rich.: ecologicallylimited effects of gene flow. Lindleyana 6: 228-234.

Sheviak, C. J., and P. M. Brown. 2002. Spiranthes Richard. In Flora of North America, Volume 26: Magnoliophyta: Liliida: Liliales and Orchidales. Edited by Flora of North America Editorial Committee. Oxford University Press, New York, USA.

Swink, F., and G. Wilhelm. 1994. Plants of the Chicago Region. Fourth edition. Indiana Academy of Science, Lisle, Indiana, USA.

Voss, E. G., and A. A. Reznicek. 2012. Field Manual of Michigan Flora. University of Michigan Press, Ann Arbor, Michigan, USA.

Weakley, A. S., J. C. Ludwig, and J. Townsend. 2012. Flora of Virginia. Botanical Institute of Texas Press, Fort Worth, Texas, USA.

Whiting, R. E., and P. M. Catling. 1986. Orchids of Ontario, an illustrated guide. CanaColl Foundation, Ottawa, Ontario, Canada.

Received 23 December 2014

Accepted 3 February 2015 